\title{
Pengaruh Service Marketing, Relationship Marketing, Communication Marketing Terhadap Customer Satisfaction
}

\author{
Devita Anggraeni ${ }^{1,}$ Chandra Kartika ${ }^{2}$ \\ Program Studi Manajemen \\ ${ }^{1,2}$ Fakultas ekonomi dan Bisnis Universitas Wijaya Putra \\ '1devita.depdep@gmail.com, ${ }^{2}$ chandrakartika@uwp.ac.id
}

\begin{tabular}{l}
\hline Article Info \\
\hline Article history: \\
Received 7 Januari 2022 \\
Accepted 8 Januari 2022 \\
Published 8 Januari 2022 \\
Page : 56 - 67 \\
\hline
\end{tabular}

Keyword:

Total Quality

Management (TQM),

Manajemen Operasional,

Intanaya Tour and Travel

\begin{abstract}
This study aims to determine: Is there any influence of Service Marketing, Relation Marketing and Communication Marketing simultaneously affect the Customer Satisfaction of Motorcycle users at Surya Gemilang Motor Surabaya Barat, Is there any influence of Service Marketing partially affect the Customer Satisfaction of Motorcycle users at Surya Gemilang Motor Surabaya West, Is there any influence of Relationship Marketing which partially affects Customer Satisfaction of Motorcycle users at Surya Gemilang Motor, West Surabaya, Is there any influence of Communication Marketing that partially affects Customer Satisfaction of Motorcycle users at Surya Gemilang Motor, West Surabaya. The population in this study are customers who use Honda motorcycles. The sampling technique used was accidental sampling. The data collection technique used a questionnaire that had been tested for validity and reliability. The data analysis technique used is multiple regression. The results of this study indicate that Service Marketing, Relation Marketing and Communication Marketing variables simultaneously have a Positive and Significant effect on Customer Satisfaction of Motorcycle users at Surya Gemilang Motor, West Surabaya. Relationship Marketing partially has no effect on Customer Satisfaction of Motorcycle users at Surya Gemilang Motor, West Surabaya. Keywords: Service marketing, relationship marketing, marketing communication, customer satisfaction
\end{abstract}

Penelitian ini bertujuan untuk mengetahui apakah ada pengaruh Service Marketing, Relation Marketing dan Communication Marketing secara simultan berpengaruh terhadap Customer Satisfaction pengguna Motor di Surya Gemilang Motor Surabaya Barat, Apakah ada pengaruh Service Marketing secara parsial berpengaruh terhadap Customer Satisfaction pengguna Motor di Surya Gemilang Motor Surabaya Barat, Apakah ada pengaruh Relationship Marketing secara parsial berpengaruh terhadap Customer Satisfaction pengguna Motor di Surya Gemilang Motor Surabaya Barat, Apakah ada pengaruh Communication Marketing secara parsial berpengaruh terhadap Customer Satisfaction pengguna Motor di Surya Gemilang Motor Surabaya Barat. Populasi dalam penelitian ini adalah pelanggan yang menggunakan sepeda motor Honda. Teknik pengambilan sampel menggunakan Accidental sampling, Teknik pengumpulan data menggunakan kuesioner yang telah diuji validitas dan reliabilitasnya. Teknik analisis data yang digunakan adalah regresi berganda. Hasil penelitian ini menunjukan bahwa Variabel Service Marketing, Relation Marketing dan Communication Marketing secara simultan berpengaruh Positif dan Siginifikan terhadap Customer Satisfaction pengguna Motor di Surya Gemilang Motor Surabaya Barat Variabel Service Marketing secara parsial tidak berpengaruh terhadap Customer Satisfaction pengguna Motor di Surya Gemilang Motor Surabaya Barat Variabel Relationship Marketing secara parsial tidak berpengaruh terhadap Customer Satisfaction pengguna Motor di Surya Gemilang Motor Surabaya Barat Variabel Communication Marketing secara parsial berpengaruh positif dan signifikan terhadap Customer Satisfaction pengguna Motor di Surya Gemilang Motor Surabaya Barat. Kata kunci: Service marketing, relationship marketing, marketing communication, customer satisfaction.

Copyright (C) 2022 Journal Of Islamic Management. All rights reserved.

\section{Editorial Office:}

Program Studi Manajemen Dakwah, Fakultas Dakwah dan Komunikasi, UIN Sunan Ampel Surabaya.

Jl. Ahmad Yani 117 Surabaya, Jawa Timur, Indonesia.

Email: jim@uinsby.ac.id 


\section{Pendahuluan}

Perkembangan globalisasi saat ini menimbulkan keinginan konsumen yang semakin meningkat, dengan meningkatnya keinginan, perusahaan di bidang otomotif ini akan semakin ketat dalam persaingan, sepeda motor sendiri adalah alat transportasi yang paling diminati oleh kosumeen karena penggunaannya yang praktis. Untuk menciptakan kepuasan konsumen, perusahaan juga dituntut tidak hanya didasarkan pada fungsi sepeda motor tetapi membangun komunikasi terhadap konsumen juga dinilai sangat penting dalam meningkatkan kepuasan. Sepeda motor merupakan pengembangan dari sepeda konvensional yang lebih dahulu ditemukan dahulu sepeda motor hanya digunakan dengan tujuan untuk alat transportasi saja tetapi seiring perkembangan jaman sepeda motor mulai beralih fungsi.

Pelanggan saat ini lebih melihat dari sisi merek, promosi bahkan model dari sepeda motor, dan bukan dari fungsi aslinya yaitu hanya sebagai alat transportasi saja tetapi seiring berkembangnya jaman sepeda motor di modifikasi untuk memenuhi hobi. Sepeda motor merupakan alat transportasi yang banyak di gunakan di Indonesia, terutama di Surabaya. Dalam penggunaanya sepeda motor tidak lepas dari perawatan rutin dan penggantian suku cadangnya yang biasanya di lakukan di bengkel.

Honda didirikan pada 24 september 1948 oleh Bapak Soichiro Honda. Honda merupakan produsen sepeda motor terbesar di dunia sejak 1959, dan juga produsen mesin pembakaran dalam terbesar dengan produksi lebih dari 20 juta unit tiap tahun. Pada tahun 2014, Honda menginvestasikan sekitar $10,7 \%$ (US \$ 16,8 miliar) dari pendapatanya untuk penelitian dan pengembangan.

Hal ini ditunjukkan dari merek terlaris sebagai merek sepeda motor yang banyak dipakai oleh masyarakat Indonesia. Di urutan pertama ada Honda Beat yang mencapai penjualan sebesar 1.9 juta unit, selanjutnya di urutan kedua masih ada Honda Vario yang menunjukkan total penjualan yang tidak jauh dari Honda Beat, yaitu sebesar 1,2 juta unit. Dari pergerakan penjualan yang terus meningkat, maka dalam hal ini pihak Honda harus siap dalam penanganan setiap kekurangan atau keperluan perawatan produk yang dibeli oleh masyarakat Indonesia.

Surya Gemilang Motor yang merupakan salah satu dealer yang menjual produk kendaraan sepeda motor Honda yangberalamatkan di Jl. Raya Babat Jerawat, Pakal,Surabaya. Bukan hanya sebagai perusahaan dengan divisi penjualan namun juga menyediakan layanan perawatan (service) sepeda motor serta penjualan suku cadang sepeda motor. Sebagai perusahaan pelayanan jasa, maka Surya Gemilang Motorharus berusaha menciptakan kepuasan terhadap pelanggan tersebut dengan memberikan pelayanan yang di inginkan oleh pelanggan. Sehingga pelanggan merasa puas terhadap pelayanan yang diberikan perusahaan.

Menurut Kurniasari dan Ernawati (2012) mengatakan bahwa kepuasan pelanggan akan menimbulkan sikap senang terhadap transaksi dan memberikan dampak besar pada kelangsungan usaha atau hubungan jangka panjang. Sedangkan menurut Muktiono (2014) mengatakan bahwa kepuasan pelanggan akan mempengaruhi sikap pelanggan berikutnya setelah menggunakan atau merasakan produk maupun jasa yang di tawarkan, oleh karena itu pelanggan yang merasa puas akan mengulangi menggunakan jasa yang ditawarkan. Service marketing merupakan suatu proses penciptaan dan penyam-paian barang dan jasa yang diinginkan pelanggan, yang meliputi kegiatan yang berkaitan dengan menarik dan mempertahankan pelanggan, sebagai pemenuhan keinginan dan kebutuhan perusahaan. Zeithaml dan Bitner (2010) menyatakan bahwa pemasaran jasa adalah 
mengenai janji-janji yang dibuat kepada konsumen dan harus dijaga.

Lovelock dan Wirtz menyatakan bahwa pemasaran jasa adalah bagian dari sistem jasa keseluruhan dimana perusahaan tersebut memiliki sebuah bentuk kontak dengan konsum-ennya, mulai dari pengiklanan hingga penagihan, hal itu mencakup kontak yang dilakukan pada saat penyerahan jasa. Salah satu strategi yang dapat diterapkan dalam mempertahankan pelanggan dengan menciptakan hubungan relation-ship yang baik dengan pelanggan. Hubungan Pemasaran merupakan proses berkelanjutan yang mensyaratkan suatu perusahaan agar menjalin komunikasi tetap dengan pelanggan untuk memastikan tujuan perusahaan tercapai, dan memadukan proses relationship marketing kedalam rencana strategik sehingga memungkinkan perusahaan mengelola sumber daya dengan baik dan dapat memenuhi kebutuhan pelanggan di waktu mendatang Kotler \& Amstrong (2012) Hubungan Pemasaran yaitu proses menciptakan, mempertahankan, dan memperbaiki hubungan kuat yang bedasarkan nilai, dengan pelanggan dan pemegang saham lainya.

Menurut shimp (2015) mengatakan bahwa komunikasi adalah proses dimana pemikiran dan pemahaman disampaikan antar individu atau antar individu dengan kelompok. Kotler dan Keller (2015) komunikasi pemasaran adalah sarana yang digunakan perusahaan dalam upaya untuk menginformasikan, membujuk dan meningkatkan konsumen - langsung atau tidak langsung tentang produk dan merek yang meraka jual. Research gap yang terjadi pada penelitian Ristiani (2017) yang meng-ungkapkan tentang Pengaruh Sarana Prasarana dan Kualitas Pelayanan terhadap Kepuasan Pasien (Studi Kasus Pasien Rawat Jalan Unit Poliklinik IPDN Jatinangor). Hasil penelitian ini meyatakan bahwa sarana prasarana dan kualitas pelayanan kesehatan memberikan peng- aruh yang kuat terhadap kepuasan pasien. Selanjutnya penelitian Khoirista, et al (2015) yang mengungkapkan tentang Pengaruh Kualitas Pelayanan terhadap Kepuasan Pelanggan (Survey pada Pelanggan Fedex Express Surabaya).

Hasil penelitian ini menyatakan kualitas pelayanan yang terdiri variabel tangible, reliability, responsiveness, assurance, empathysecara simultan memiliki pengaruh yang positif terhadap kepuasan pelanggan. Research gap selanjutnya pada penelitiannya Putri (2017) yang mengungkapkan tentang pengaruh Relationshipmarketing dan citra merk perusahaan terhadap Loyalitas pelanggan (Studi Pada Hotel Sapadia Kecamatan pasir Pengaraian). Hasil penelitian ini menyatakan bahwa setelah dilakukan penelitian terhadap variabel Hubungan Pemasaranpada hotel Sapadia Kecamatan Pasir Pengaraian dapat diketahui bahwa skor berada pada kategori setuju, artinya Hubungan Pemasaran pada hotel Sapadia Kecamatan Pasir Pangaraian terlaksana dengan baik dan sesuai dengan keinginan tamu. Selanjutnya penelitian Wardani et al. (2017) yang mengungkapkan tentang Pengaruh Hubungan Pemasaran Tehadap Loyalitas (Survei Pada Nasabah Tabungan Britama PT. Bank Rakyat Indonesia (persero) Tbk. Kantor Cabang Gresik). Hasil penelitian ini berpengaruh positif dan signifikan karena jika perusahaan meningkatkan relationship marketing maka kepuasan pelanggan akan meningkat.

Selanjutnya penelitian Margaretha et al. (2017) yang mengungkapkan tentang Analisis Komunikasi Pemasaran Terpadu PT. Consulting dalam Membangun Brand Association. Hasil penelitian mengatakan bahwa kegiatan komunikasi pemasaran terpadu oleh CUBES dalam membangun Brand imagedi mata konsumen, memang tidak mencakup semua kegiatan yang ada menurut teori yang dikemukakan oleh Kotler Keller. 
Selanjutnya penelitian Siswantini et al. (2017) yang mengungkapkan tentang Pengaruh Komunikasi Pemasaran, Pengalaman Dan Kualitas Jasa Terhadap Citra Dan Kepuasan Serta Dampaknya Pada Loyalitas Wisatawan Nusantara (Survei Tempat Rekreasi Air Terjun Di Kabupaten Bogor).

Hasil penelitian mengatakan bahwa komunikasi pemasaran berhubungan signifikan terhadap citra. Hal ini menunjukan bahwa komunikasi yang menarik akan membentuk citra yang positif dan mendorong wisatawan berkunjung. Fenomena yang terjadi saat ini adalah konsumen lebih cenderung untuk memilih tempat perawatan motor yang memiliki fasilitas dan kehandalan yang dirasa sesuai akan tingkat kepuasaannya, antara lain : Pelanggan akan cenderung memilih bengkel yang memberikan pelayanan yang cepat dan selalu memenuhi keinginannya dalam hal perbaikan maupun perawatan sepeda motor, kemampuan teknisi sepeda motor yang handal dan cukup dikenal baik dalam menangani setiap kendala yang di keluhkan pelanggan, dan layanan informasi yang berjalan efektif dalam memperhatikan hubungan karyawan dengan pelanggan yang mana akan menciptakan komunikasi yang baik agar pelanggan merasa diperhatikan oleh perusahaan.

\section{Kajian Pustaka}

\section{Kepuasan Pelanggan (Customer Satisfaction)}

Menurut Kotler (dalam Lupiyoadi, 2013), mendefinisikan tentang kepuasan merupakan tingkat perasaan di mana seseorang menyatakan hasil perbandingan atas kinerja produk (jasa) yang diterima dan yang diharapkan. Selanjutnya Menurut Hasan (2014), menyatakan bahwa kepuasan atau ketidakpuasan merupakan respons konsumen terhadap evaluasi ketida kpuasan yang dipersepsikan antara harapan sebelum pembelian dari kinerja aktual produk atau jasa yang dirasakan setelah pemakaiannya. Selanjutnya teori

2. Service Marketing (Pemasaran Jasa) Pemasaran jasa merupakan ilmu yang relatif baru. Industri jasa pada saat ini merupakan sektor ekonomi yang sangat besar dan tumbuh sangat pesat.Pertumbuhan tersebut akibat dari tuntuan dan perkembangan teknologi. Kondisi tersebut secara langsung menghadapkan para pelaku bisnis kepada permasalahan persaing-an usaha yang semakin tinggi, semakin tingginya tingkat persaingan sehingga diperlukan manajemen pemasaran jasa yang berbeda dibandingkan dengan pemasaran tradisional (barang).Yazid (2008) mengatakan bahwa Pemasaran jasa merupakan penghubung antara organisasi dengan konsumennya. Peran penghubung ini akan berhasil bila semua upaya pemasaran diorientasi-kan kepada pasar.

3. Komunikasi Pemasaran (Communication Marketing )

Komunikasi pemasaran menyebutkan bahwa yang termasuk dalam bentuk komunikasi pemasaran terpadu antara lain periklanan, promosi penjualan, publisitas, penjualan perseorangan, hubungan masyarakat dan penjualan langsung, kemasan, sponsorship dan customer service. Komunikasi pemasaran merupakan aktivitas pemasaran yang berusaha menciptakan kesadaran atau pengetahuan mengenai produk dengan berbagai atributnya, menginformasikan kelebihan produk, menciptakan citra produk, atau menciptakan sikap positif, preferensi, dan keinginan membeli produk yang bersangkutan. Komunikasi merupakan usaha untuk menyampaikan pesan kepada publik terutama konsumen saran mengenai perbedaan produk di pasar. Kegiatan komunikasi pemasaran merupakan rangkaian kegiatan untuk mewujudkan suatu produk, jasa, ide, dengan menggunakan bauran pem- 
asaran (marketing mix) yaitu iklan (advertising), penjualan tatap muka (sales promotion), hubungan masyarakat dan publisitas (public relation and publicity) serta pemasaran langsung (direct marketing) Sutisna dalam Amir Purba, dkk (2006).

\section{Metode Penelitian}

\section{Jenis dan Pendekatan Penelitian}

Jenis penelitian ini menggunakan pendekatan kuantitatif, karena penelitian ini disajikan dengan angkaangka.Hal ini sesuai dengan pendapat Ferdinand (2012) yang mendifinisikan bahwa penelitian kuantitatif adalah

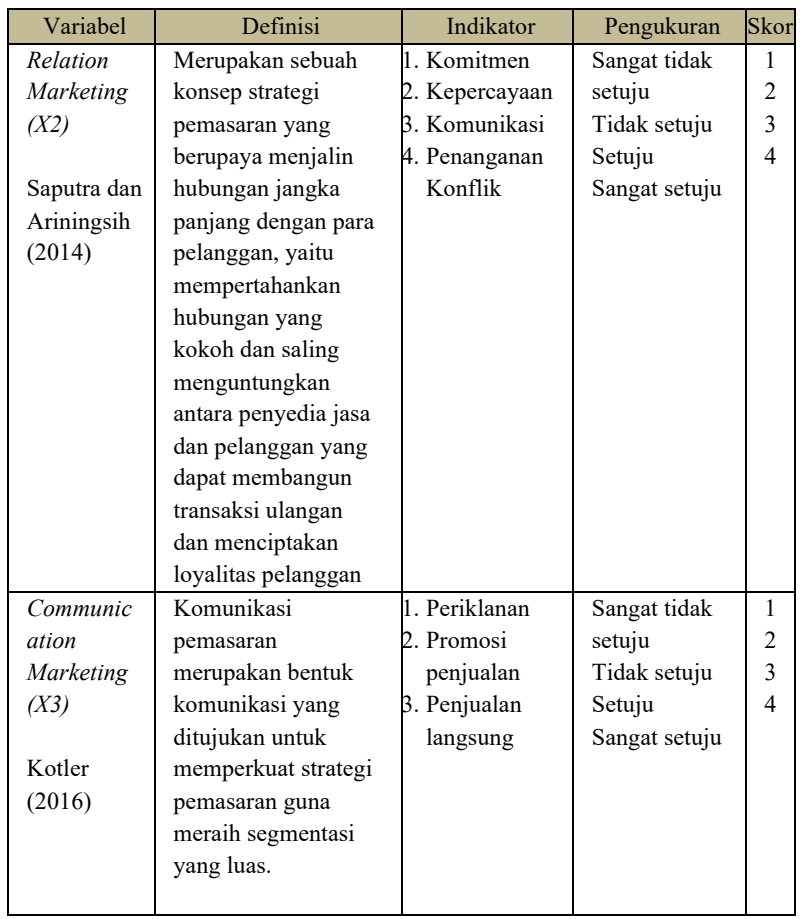

pendekatan penelitian yang banyak dituntut mengungkankan angka, mulai dari pengumpulan data, penafsiran terhadap data tersebut, serta penampilan hasilnya.Hal tersebut didukung oleh Sugiyono (2012) yang mengartikan bahwa penelitian kuantitatif adalah penelitian yang berlandaskan pada filsafat positivism, digunakan untuk meneliti pada populasi atau sampel tertentu.

\section{Variabel Penelitian}

Dalam penelitian ini, peneliti menggunakan 2 jenis variabel, yaitu variabel bebas dan variabel terikat. Dalam penelitian ini variabel bebas (X) pada gunakan adalah Service Marketing $\left(\mathrm{X}_{1}\right)$, Relationship Marketing $\left(\mathrm{X}_{2}\right)$, dan Communication Marketing $\left(\mathrm{X}_{3}\right)$ dan Variabel terikat (Y) pada penelitian ini adalah Customer Satisfaction (kepuasan pelanggan) pelanggan pengguna Motor Surya Gemilang Motor cabang Surabaya Barat.

\section{Definisi Operasional Variabel}

Operasionalisasi variabel diperlukan untuk menentukan jenis, indikator, serta skala dari variabel-variabel yang terkait dalam penelitian, sehingga pengujian dapat dilakukan secara benar. Operasional variabel dalam penelitian tentang kepuasan pelanggan Surya Gemilang Motor cabang Surabaya Barat akan dijelaskan dalam tabel berikut ini

\begin{tabular}{|c|c|c|c|c|}
\hline Variabel & Definisi & Indikator & Pengukuran & Skor \\
\hline $\begin{array}{l}\text { Customer } \\
\text { Satisfaction } \\
\text { (Y) } \\
\text { Kotler } \\
(2014)\end{array}$ & $\begin{array}{l}\text { Kepuasan. merupakan } \\
\text { tingkat perasaan di } \\
\text { mana seseorang } \\
\text { menyatakan hasil } \\
\text { perbandingan atas } \\
\text { kinerja produk (jasa) } \\
\text { yang diterima dan } \\
\text { yang diharapkan. }\end{array}$ & \begin{tabular}{|l|} 
1. Kesesuaian \\
harapan \\
2. Minat \\
berkunjung \\
kembali \\
3. Kesediaan \\
merekomendas \\
i
\end{tabular} & $\begin{array}{l}\text { Sangat tidak } \\
\text { setuju } \\
\text { Tidak setuju } \\
\text { Setuju } \\
\text { Sangat setuju }\end{array}$ & $\begin{array}{l}1 \\
2 \\
3 \\
4\end{array}$ \\
\hline $\begin{array}{l}\text { Service } \\
\text { Marketing } \\
(X 1) \\
\\
\text { Yazid } \\
(2008)\end{array}$ & $\begin{array}{l}\text { Pemasaran jasa } \\
\text { merupakan } \\
\text { penghubung antara } \\
\text { organisasi dengan } \\
\text { konsumennya. Peran } \\
\text { penghubung ini akan } \\
\text { berhasil bila semua } \\
\text { upaya pemasaran } \\
\text { diorientasikan kepada } \\
\text { pasar. }\end{array}$ & $\begin{array}{l}\text { 1. Bukti fisik } \\
\text { 2. Kehandala } \\
\mathrm{n} \\
\text { 3. Daya } \\
\text { tanggap }\end{array}$ & $\begin{array}{l}\text { Sangat tidak } \\
\text { setuju } \\
\text { Tidak setuju } \\
\text { Setuju } \\
\text { Sangat setuju }\end{array}$ & $\begin{array}{l}1 \\
2 \\
3 \\
4\end{array}$ \\
\hline
\end{tabular}

\section{Lokasi Penelitian}

Penelitian ini dilakukan di Surya Gemilang Motor cabang Surabaya Barat J1. Raya Babat Jerawat No.8, Babat Jerawat, Pakal, Kota Surabaya, Jawa Timur dengan mengambil sampel acak dan mengambil responden dari pengguna sepeda motor Honda. Peneliti menetapkan lokasi tersebut dalam penelitian ini karena ingin mengetahui bagaimana Service Marketing, Relation Marketing, Komunikasi, Communi- 
cation Marketing berpengaruh terhadap Customer Satisfaction PT. Surya Gemilang Motor cabang Surabaya Barat

\section{Kerangka Konseptual}

Menurut Haryoko dalam Iskandar (2014) Secara teoritis model konseptual variabel-variabel penelitian, tentang bagaimana pertautan teori-teori yang berhubungan dengan variabel-variabel penelitian yang ingin diteliti, yaitu variabel terikat . Berdasarkan teori yang telah dijelaskan, hubungan antara dimensi Service Marketing, Hubungan Pemasaran, Komunikasi Pemasaran terhadap Kepuasan Pelanggan di Surya Gemilang Motor Surabaya secara parsial dan simultan bisa dilihat dari gambar berikut:

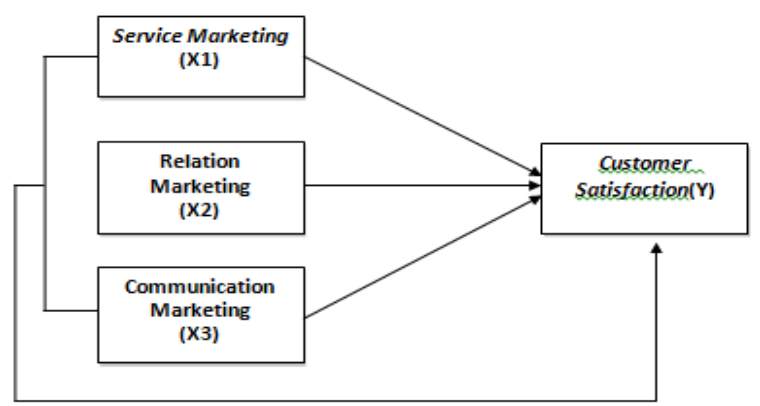

Gambar 1: Kerangka Konseptual

\section{Hipotesis}

Berdasarkan rumusan masalah serta tujuan penelitian yang telah diuraikan diatas, maka hipotesis dalam penelitian ini adalah:

1) Ada pengaruh Service Marketing, Relationship Marketing dan Communication Marketing secara simultan berpengaruh positif dan signifikan terhadap Customer Satisfaction pengguna Motor di Surya Gemilang Motor Surabaya Barat ?

2) Ada pengaruh Service Marketing berpengaruh positif dan signifikan terhadap Customer Satisfaction pengguna Motor di Surya Gemilang Motor Surabaya Barat ?

3) Ada pengaruh Relationship Marketing berpengaruh positif dan signifikan terhadap Customer Satisfaction pengguna Motor di Surya Gemilang Motor Surabaya Barat ?

4) Ada pengaruh Communication Marketing berpengaruh positif dan signifikan terhadap Customer Satisfaction pengguna Motor di Surya Gemilang Motor Surabaya Barat ?

\section{Populasi, Sampel Dan Teknik Pengambilan Sampel}

Populasi dalam penelitian ini seluruh pengguna motor PT. Surya Gemilang Motor yang jumlahnya tidak terbatas dikarekana secara empiris di PT. Surya Gemilang Motor tidak mencatat jumlah pelanggan yang menggunakan Motor Honda tersebut. Sampel sejumlah 100 responden, Menurut Metode pengambilan sampel dalam penelitian ini menggunakan teknik accidental sampling. Menurut Sugiyono (2016) mendifisinikan bahwa teknik accidental sampling adalah teknik untuk menentukan sampel dari populasi yang mempunyai ciri-ciri tertentu sampai jumlah kuota yang diinginkan. Adapun kriteria-kriteria penentuan sampel yang digunakan dalam penelitian ini adalah sebagai berikut :

1. Warga Negara Indonesia

2. Pengguna sepeda motor Merk Honda

3. Pengguna berusia antara $18-45$ Tahun

4. Pelanggan yang sering berkunjung dan melakukan transaksi pada PT. Surya Gemilang Motor Pakal Surabaya

\section{Instrumen Penelitian}

Arikunto (2014) instrumen penelitian adalah alat yang digunakan oleh peneliti dalam mengumpulkan data agar pekerjaan lebih mudah dan hasilnya lebih baik.Sugiyono (2016) mengemukakan bahwa instrument penelitian merupakan alat yang dapat digunakan untuk mengumpulkan data atau informasi penelitian. Alat yang digunakan oleh peneliti sebagai alat pengumpulan data adalah tes dan lembar observasi

\section{Teknik Analisis Data}

Sugiyono (2016) menjelaskan analisis data merupakan proses mencari dan 
menyusun secara sistematis data yang diperoleh dari hasil catatan lapangan, dan bahan - bahan lain sehingga mudah dipahami, dan temuannya bisa diinformasikan pada orang lain.

\section{Analisis Regresi Linear Berganda}

Sugiono (2015) menyatakan Analisis ini digunakan untuk menganalisis pengaruh dari berbagai vaiabel independen (bebas), yaitu Service Marketing, Relationship Marketing, Communication Marketing terhadap satu variabel dependen (terikat), yaitu Customer Satisfation.

\section{Hasil dan Pembahasan}

Gambaran Secara Deskriptif Pengaruh Service Marketing, Relationship Marketing, Communication Marketing dan Customer Satisfaction

Dari hasil penelitian ini, menunjukkan bahwa Gambaran tentang customer satisfaction pada PT. Surya Gemilang Motor Surabaya antara lain Fasilitas yang diberikan oleh Surya Gemilang Motor kepada pelanggan mayoritas responden mengatakan "setuju" bahwa Service Marketing yang dilakukan oleh Surya Gemilang Motor sesuai yang diinginkan pelanggan. Surya Gemilang Motor Memberikan pelayanan yang cepat dan tepat pada pelanggan mayoritas responden mengatakan "setuju" bahwa Service Marketing Surya Gemilang motor memberikan pelayanan dengan tepat dan cepat.

Dan Surya Gemilang Motor sangat responsive terhadap pelanggan mayoritas responden mengatakan "setuju" bahwa Service Marketing yang dilakukan oleh Surya Gemilang Motor memberi sikap responsive terhadap pelanggan. Dan dalam Relation Marketing diantaranya Surya Gemilang Motor berpartisipasi dalam event Otomotif mayoritas responden mengatakan "setuju" bahwa Hubungan Pemasaran (hubungan pemasaran) yang dilakukan Surya Gemilang Motor dalam berpartisipasi dengan event otomotif . Percaya bahwa Surya Gemilang Motor mempunyai kualitas produk dan pelayanan yang baik mayoritas responden mengatakan "setuju" bahwa Relationship Marketing yang dilakukan oleh Marketing Surya Gemilang Motor dapat di percaya oleh pelanggan.

Hubungan pemasaran dilakukan Surya Gemilang Motor menjadi daya tarik tersendiri dengan menyampaikan langsung kepada pelanggan mayoritas responden mengatakan "setuju" bahwa Hubungan Pemasaran yang dilakukan oleh Surya Gemilang Motor dengan menyampaiakan langsung kepada pelanggan. Surya Gemilang Motor mempunyai sikap simpatik mayoritas responden menyatakan "setuju" bahwa Surya Gemilang Motor selalu menunjukan simpatik. Surya Gemilang Motor menggunakan media iklan cetak dan elektronik guna mendorong minat beli mayoritas responden menyatakan "setuju" bahwa Komunikasi Marketing Surya Gemilang motor dengan media cetak dan elektronik bisa di terima pelanggan.

Surya Gemilang Motor memberikan merchandise sebagai daya Tarik bagi pelanggan mayoritas responden menyatakan "setuju" bahwa pembagian merchandise oleh Surya Gemilang Motor sesuai yang diharapkan pelanggan. Surya Gemilang Motor menggunakan promosi lewat telepon mayoritas responden menyatakan "setuju" bahwa Komunikasi Marketing menggunakan promosi lewat telepon sesuai dengan harapan pelanggan.

Pengaruh Service marketing, Relationship Marketing, Communication Marketing secara Simultan Terhadap Customer Satisfaction

Dari hasil penelitian dikemukakan bahwa Service marketing, Relationship Marketing, Communication Marketing secara simultan (bersama-sama) berpengaruh positif terhadap Customer satisfaction. Hal ini ditunjukkan dari nilai signifikan $F=0,000<0,05$. Pengaruh antara variabel bebas terhadap Marketing Customer satisfaction membuktikan bahwa semakin kecil variabel bebas, maka 
akan meningkatkan Customer satisfaction Nilai R-Square berarti variasi atau perubahan dari Customer satisfaction dipengaruhi bersama-sama oleh Service marketing, Relationship marketing dan Customer satisfaction sedangkan sisanya dari variasi atau perubahan Customer satisfaction disebabkan oleh variabel lain yang tidak disertakan dalam penelitian ini. Selain tiga variabel tersebut masih banyak faktor - faktor lain yang mempengaruhi Customer satisfaction.

Ini berarti pelanggan atau calon pelanggan mempunyai niat untuk menggunakan jasa layanan Surya Gemilang Motor karena adanya penerapan secara bersama - sama dari Service marketing, Relationship marketing, Communication Marketing serta faktor - faktor lainnya yang tidak disertakan dalam penelitian ini. Hasil penelitian ini sesuai dengan pendapat Murwatiningsih (2012), mendefinisikan kinerja adalah hasil yang telah dicapai dari apa yang telah dilakukan oleh pemilik atau manajer dalam menjalankan bisnis, dan Kinerja pemasaran dapat diukur dengan menggunakan pertumbuhan penjualan, pertumbuhan pelanggan dan keberhasilan produk atau jasa serta dimensi-dimensi lainnya yang mendukung untuk meningkatkan kepuasan pelanggan.

Dalam penelitian ini didukung oleh penelitian Kartika, (2019) bahwa pengaruh positif relationship marketing, komunikasi pemasaran dan citra perusahaan terhadap niat perilaku konsumen melalui kepuasan pelanggan pada vasa hotel surabaya. Dan Didukung oleh Penelitian Anwar alanasi, et.,al ( 2016) Mengatakan bahwa secara simultan service marketing, relationship marketing, dan Communication Marketing berpengaruh terhadap tingkat Customer Satisfaction.

\section{Pengaruh Service Marketing Terhadap Customer Satisfaction}

Nilai koefisien regresi variabel $\mathrm{X}_{1}$ (Service marketing) menunjukan bahwa jika variabel Service marketing berubah satu satuan, maka variabel Y (Customer Satisfaction) berubah sebesar nilai koefisiennya dengan asumsi variabel lainnya tetap. Nilai koefisien bertanda positif berarti arah hubungannya searah. Artinya jika Service marketing meningkat, maka Kepuasan Pelanggan akan meningkat. Nilai signifikansi $\mathrm{t}$ untuk variabel $\mathrm{X}_{1} \quad$ (Service marketing) menunjukkan lebih besar dari standarisasi tingkat signifikan. Dengan demikian variabel $\mathrm{X}_{1}$ (Service marketing) tidak berpengaruh secara signifikan terhadap variabel Y (Kepuasan Pelanggan). Hal ini terjadi karena Surya Gemilang Motor belum bisa memaksimalkan Service marketing kepada pelanggan atau calon pelanggan dalam meningkatkan Kepuasan Pelanggan melalui indikator Service marketing.

Hasil penelitian ini didukung oleh penelitian Rokhmat Subagiyo, M. Aqim Adlan, (2017) yaitu Service Marketing tidak berpengaruh signifikan terhadap kepuasan mahasiswa, bauran pemasaran berpengaruh signifikan terhadap kepuasan mahasiswa, kualitas pelayanan tidak berpengaruh signifikan terhadap loyalitas mahasiswa, bauran pemasaran berpengaruh signifikan terhadap loyalitas mahasiswa dan kepuasan mahasiswa berpengaruh signifikan terhadap loyalitas mahasiswa.

\section{Pengaruh Relationship Marketing Terhadap Customer Satisfaction}

Nilai koefisien regresi variabel $\mathrm{X}_{2}$ (Relationship Marketing) menunjukan positif hal ini berarti bahwa jika variabel Hubungan Pemasaran berubah satu satuan, maka variabel Y (Kepuasan Pelanggan) berubah sebesar nilai koefisiennya dengan asumsi variabel lain tetap. Nilai koefisien berubah positif berarti arah hubungannya searah. Artinya jika Kepuasan Pelanggan meningkat maka Kepuasan Pelanggan akan meningkat dan sebaliknya. Nilai signifikansi uji t untuk variabel $\mathrm{X}_{2}$ (Relationship Marketing) menujukan lebih besar dari standarisasi tingkat signifikan. 
Dengan demikian variabel $\mathrm{X}_{2}$ (Relationship Marketing) tidak berpengaruh terhadap variabel Y (Customer Satisfaction). Hal ini terjadi karena Surya Gemilang Motor belum bisa memaksimalkan Relationship Marketing kepada pelanggan atau calon pelanggan dalam meningkatkan Kepuasan Pelanggan melalui indikator Relationship Marketing. Hal ini didukung oleh penelitian Ndubisi (2004) menyatakan bahwa relationship marketing tidak berpengaruh positif terhadap tingkat kepuasan pelangan. Dari pengertian tersebut Ndubisi berpendapat bahwa untuk membangun hubungan yang baik perusahaan harus melakukan sebuah pengorbanan tertentu, dimana hal tersebut memang dirancang untuk menumbuhkan kepuasan pelanggan tetapi lain hal ini secara empiris penelitian tersebut menyatakan tidak berpengaruh terhadap kepuasan pelanggan. Sedangkan menurut Peng and Wang (2006) define relationship marketing as all marketing activities directed towards building customer loyalty (keeping and winning customers) by providing value to all the parties involved in the relational exchanges" artinya kegiatan untuk membangun loyalitas pelanggan (menjaga dan memenangkan pelanggan) dengan memberikan nilai bagi semua pihak yang terlibat dalam pertukaran relasional. Dari pengertian tersebut telah dapat disimpulkan bahwa relationship marketing memiliki hubungan keterikatan dengan terbentuknya tingkat kepuasan. Tetapi dalam penelitian Evan \& Laskin (2014) menyatakan bahwa relationship marketing tidak berpengaruh signifikan terhadap kepuasan.

\section{Pengaruh Communication Marketing Terhadap Customer Satisfaction}

Dan Nilai koefisien regresi variabel $\mathrm{X}_{3}$ (Communication Marketing) menunjukan positif, hal ini berarti bahwa jika variabel Communication Marketing berubah satu satauan, maka variabel Y (Customer Satisfaction) berubah sebesar nilai koefisiennya dengan asumsi variabel lainnya tetap. Nilai koefisien bertanda positif berarti arah hubungannya searah. Artinya jika Communcation Marketing meningkat maka Customer Satisfaction akan meningkat. Nilai signifikansi t untuk variabel $\mathrm{X}_{3}$ (Communcation Marketing) menunjukan positif dengan nilai taraf signifikan 0,000 $>0,05$. Dengan demikian variabel $\mathrm{X}_{3}$ (Communcation Marketing) berpengaruh terhadap variabel $\mathrm{Y}$ (Customer Satisfaction). Hal ini disebabkan karena pentingnya perusahaan menerapkan Communcation Marketing agar pelanggan lebih percaya terhadap kinerja perusahaannya dan akan mengakibatkan customer satisfaction. Hal ini didukung oleh penelitian nya Nurul Afriza. (2018) penelitian ini didapatkan setelah analisa data melalui tahapan analisa tabel tunggal, analisa tabel silang dan pengujian hipotesis. Dengan demikian berdasarkan penelitian tentang Studi Korelasional Tentang Pengaruh komunikasi pemasaran Terhadap Kepuasan Pengunjung Di Tasbi Swimming Pool dapat disimpulkan bahwa berdasarkan penelitian yang sudah ada, didapatkan hasil bahwa komunikasi pemasaran sangat berpengaruh terhadap tingkat kepuasan.

\section{Kesimpulan}

Customer satisfaction pada PT. Surya Gemilang Motor Surabaya antara lain Fasilitas yang diberikan oleh Surya Gemilang Motor kepada pelanggan mayoritas responden mengatakan "setuju" bahwa Service Marketing yang dilakukan oleh Surya Gemilang Motor sesuai yang diinginkan pelanggan Surya Gemilang Motor Memberikan pelayanan yang cepat dan tepat pada pelanggan mayoritas responden mengatakan "setuju" bahwa Service Marketing Surya Gemilang motor memberikan pelayanan dengan tepat dan cepat. Dan Surya Gemilang Motor sangat responsive terhadap pelanggan mayoritas responden mengatakan "setuju" bahwa Service Marketing yang dilakukan oleh 
Surya Gemilang Motor memberi sikap responsive terhadap pelanggan.

Dan dalam Relation Marketing diantaranya Surya Gemilang Motor berpartisipasi dalam event Otomotif mayoritas responden mengatakan "setuju" bahwa Hubungan Pemasaran (hubungan pemasaran) yang dilakukan Surya Gemilang Motor dala $\mathrm{m}$ berpartisipasi dengan event otomotif . Percaya bahwa Surya Gemilang Motor mempunyai kualitas produk dan pelayanan yang baik mayoritas responden mengatakan "setuju" bahwa Relationship Marketing yang dilakukan oleh Marketing Surya Gemilang Motor dapat di percaya oleh pelanggan. Hubungan pemasaran dilakukan Surya Gemilang Motor menjadi daya tarik tersendiri dengan menyampaikan langsung kepada pelanggan mayoritas responden mengatakan "setuju" bahwa Hubungan Pemasaran yang dilakukan oleh Surya Gemilang Motor dengan menyampaiakan langsung kepada pelanggan. Surya Gemilang Motor mempunyai sikap simpatik mayoritas responden menyatakan "setuju" bahwa Surya Gemilang Motor selalu menunjukan simpatik. Surya Gemilang Motor menggunakan media iklan cetak dan elektronik guna mendorong minat beli mayoritas responden menyatakan "setuju" bahwa Komunikasi Marketing Surya Gemilang motor dengan media cetak dan elektronik bisa di terima pelanggan. Surya Gemilang Motor memberikan merchandise sebagai daya Tarik bagi pelanggan mayoritas responden menyatakan "setuju" bahwa pembagian merchandise oleh Surya Gemilang Motor sesuai yang diharapkan pelanggan.

Surya Gemilang Motor menggunakan promosi lewat telepon mayoritas responden menyatakan "setuju" bahwa Komunikasi Marketing menggunakan promosi lewat telepon sesuai dengan harapan pelanggan. Variabel Service Marketing, Relationship Marketing dan Communication Marketing secara simultan berpengaruh Positif dan Siginifikan terhadap Customer Satisfaction pengguna Motor di Surya Gemilang Motor Surabaya Barat. Variabel Service Marketing tidak berpengaruh terhadap Customer Satisfaction pengguna Motor di Surya Gemilang Motor Surabaya Barat .

Variabel Relationship Marketing tidak berpengaruh terhadap Customer Satisfaction pengguna Motor di Surya Gemilang Motor Surabaya Barat. Variabel Communication Marketing berpengaruh positif dan signifikan terhadap Customer Satisfaction pengguna Motor di Surya Gemilang Motor Surabaya Barat.

\section{Saran Penelitian}

Karena ditemukan tidak adanya hubungan antar variable Service marketing terhadap Customer satisfaction pada Surya Gemilang Motor maka variable tersebut harus lebih diperhatikan lagi. Hal itu apabila dibiarkan tentunya akan merugikan perusahaan dan akan tersaingi oleh competitor lain. Selanjutnya Bagi peneliti selanjutnya diharapkan dapat mengembangkan penelitian ini dengan mencari factor lain yang dapat mempengaruhi Customer satisfaction, selain itu peneliti selanjutnya juga dapat menggunakan metode lain seperti wawancara secara mendalam terhadap pelanggan sehingga bias didapatkan hasil yang lebih banyak dan bervariasi. Dan Hasil penelitian ini juga dapat digunakan sebagai dasar bagi studi selanjutnya untuk mengukur tingkat kepuasan pelanggan. Penelitian ini masih menggunakan 4 (empat ) variabel dan sampel sebanyak 100 responden. Selain itu pengambilan sampel juga bias diperluas lagi dan dikembangkan menjadi lebih banyak sehingga akan diperoleh hasil penelitian yang lebih akurat.

\section{DAFTAR PUSTAKA}

Ali Hasan, (2014). Marketing dan KasusKasus Kepuasan, Penerbit PT. Gramedia Jakart 
Anwari Alanasi \& Christian Bacth, (2016) Impact Relationship marketing, Service Marketing, Communication Marketing Terhadap Customer Satisfaction, Jurnal of Research Business and Management. Vol.01, Sept, 2016.

Berry dan Daryanto, (2011). Pengaruh Relationship dan Layanan Purna Jual Terhadap Kepuasan Pelanggan PT. Astra Internasional Isuzu Semarang. ejournal.undip.ac.id. Jurnal UNDIP Semarang

Day dalam Tse dan Wilton, (2014).Pengaruh service Quality Terhadap Kepuasan Pelanggan pada lembaga pendidikan Solocom di Surakarta. Jurnal Global Vol.01, 2014

Chandra Kartika, (2019), Pengaruh positif relationship marketing, komunikasi pemasaran dan citra perusahaan terhadap niat perilaku konsumen melalui kepuasan pelanggan pada vasa hotel surabaya. Jurnal Develop, Universitas Dr. Soetomo Surabaya, Vol.01, 2019

Ervan \& Laksin, (2014), Pengaruh Relationship marketing terhadap kepuasan, Jurnal Universitas Negeri Islam Sunan Ampel Surabaya, Vol. 01, September, 2014.

Irawan, (2009), Pengaruh kualitas Pelayanan terhadap kepuasan pelanggan restoran bebek H.Slamet. Jurnal UMS Solo Pers.Vol.01, Maret 2009

Kotler dan Keller, (2016). Manajemen Pemasaran. Edisi 12. Jakarta: Erlangga

Kotler, philip dan Kevin Lane Keller, (2011). Manajemen pemasaran. Edisi keempat belas. Jakarta: indeks

Kotler dalam Rambat Lupiyoadi, (2013). Pengaruh Kualitas Pelayanan dan Kepuasan Pelanggan Terhadap Loyalitas Pelanggan. Pers. Manajemen Pemasaran Edisi 12, Erlangga
Kotler dan Amstrong, (2008). Prinsipprinsip pemasaran jasa. Edisi 12. Jilid 1. Jakarta : Erlangga.

Kotler dan Keller, (2012). Pengaruh Komunikasi Pemasaran Terhadap Keputusan Pembelian CD JKT48 di Bandung

Khoirista dkk, (2015). Pengaruh Kualitas Pelayanan Terhadap Kepuasan Pelanggan (Survei pada pelanggan Fedex Express Surabaya)

Kurniasari, Ernawati. (2012). Pengaruh kepuasan pelanggan, kepercayaan, dan harga terhadap loyalitas pelanggan laundry kencling Semarang. Jurnal Mahasiswa QMan, 2012

Nurul Affriza, (2014), Pengaruh komunikasi pemasaran Terhadap Kepuasan Pengunjung Di Tasbi Swimming Pool, Jurnal Universitas Sumatra Utara Medan, Vol 01, 2014.

Putri, (2017). Pengaruh Relationship Marketing dan Citra merk perusahaan terhadap pelanggan. Jurnal JOM Vol.04 No. 2, 2007

Ristiani, (2017). Pengaruh Sarana dan Prasarana dan Kualitas Pelayanan Terhadap Kepuasan Pasien (Studi kasus pasien rawat jalan unit poliklinik IPDN Jatinangor). Skripsi Universitas Undip Semarang.

Siswantini dkk, (2017). Pengaruh komunikasi pemasaran, pengalaman dan kualitas jasa terhadap citra dan kepuasan serta dampaknya pada loyalitas wisatawan nusantara. Skripsi Universitas Islam Negeri Sunan Ampel Surabaya.

Lupiyoadi, Rambat, (2013). Manajemen Pemasaran Jasa. Jakarta: Salemba Empa

Lovelock dan Wirtz, (2011). Pemasaran Jasa Perspektif edisi 7. Jakarta : Erlangga

Margaretha dkk, (2017). Analisis komunikasi pemasaran terpadu PT. Consulting dalam membangun 
Brand Association. Erlangga, Jakarta.

Muktiono, (2014). Ateseden kepuasan konsumen dan minat loyalitas pada toko Mahkota Pekalongan, Jurnal Develop Vol.02, 2014

Prisgunanto, (2006). Komunikasi pemasaran, Strategi dan Taktik. Jakarta: Strategi dan Penelitian Pemasaran.

Rambat, Lupiyoadi. (2006). Manajemen Pemasaran edisi. Kedua. Jakarta: Salemba Empat.

Saputra dan Ariningsih, (2014). Kepercayaan, Communication Marketing dan Kepuasan Perbankan Nasional. Jurnal Manajemen, Vol.7, No 1, (2014).

Shimp, (2010). Komunikasi Pemasaran dan Ekuitas Merek Alfamart, Jurnal

Universitas Trunojoyo Madura, Vol. 02, Maret 2010

Sugiono, (2016), Methodologi Penelitian Bisnis, Penerbit PT. Salemba Empat

Soemanegara. (2006). Strategi Marketing Communication (Konsep Strategi dan Terapan), Bandung: PT. Alpabeta

Sutisna dalam Amir Purba, dkk. (2006). Pengantar Ilmu Komunikasi. Medan. Pustaka Bangsa Prss.

Terence, A.Shimp. (2013). Periklanan promosi dan aspek tambahan komunikasi

pemasaran, terpadu, jilid 1 edisi, Erlangga: Jakarta

Wardani dkk, (2017). Pengaruh Relationship Marketing terhadap (Survei pada nasabah tabungan Britama PT. Bank rakyat Indonesia (persero) Tbk. Jurnal STIBA Jakarta, Vol. 01, September 2017.

Yazid, (2008).Pemasaran jasa : konsep dan implenentasi. Yogyakarta Ekonisia.

Zeithaml dan Bitner dalam Daryanto, (2015). Pengaruh bauran pemasaran jasa terhadap proses keputusan penggunaan pada konsumen hotel
Poters Bandung, Pers. Erlangga. Jakarta

Zeithaml dan Bitner, (2016). Service Marketing.The McGraw Hill Companies, Inc 